\title{
From Ingenium to Virtus: The Cultivation of Talent in Seventeenth Century Dissertations from Uppsala University
}

\author{
Andreas Hellerstedt
}

\begin{abstract}
This article explores the problem of innate, natural talent vs acquired skill, knowledge, and virtue in dissertations from Uppsala University around 1680. These texts have never before been studied. It discusses questions such as: how did Swedish academics of the period conceive the relationship between ingenium (innate potential) and (acquired) virtue or knowledge? Which teaching methods did they advocate? How do the texts relate to developments in seventeenth century society? The study uses a combination of contextual analysis and a 'history of concepts' approach to answer these questions. The analysis reveals that the Swedish dissertations respond to contemporary debates (involving well-known authorities such as Vives, Huarte, Erasmus, and Comenius) and that they were affected by the immediate context: the growth of the early modern state and the social mobility which accompanied that growth. Education is described in Renaissance humanist terms, with a clear affinity to moral philosophical concepts such as virtue and habituation. The learning process described is analogous to the acquisition of moral virtue and education itself is to a large extent legitimated with reference to moral socialization. The educational ideas put forward balance discipline and playfulness, and represent a relatively democratic view of the distribution of human capabilities, showing a great trust in the potential of education. However, there is also a distinct stress on medical explanations of differences in individual talent.
\end{abstract}

Keywords • early modern education, ingenium, virtue ethics, humanism

In pre-modern societies, education was almost always a broader concept than a mere appropriation of knowledge. Its purpose was character formation: education meant teaching virtue. ${ }^{1}$ However, virtue ethics and education shared a common problem. Knowledge, like virtue, was something man $^{2}$ acquired through education, practice and

This article has been written within the cross-disciplinary research project "Teaching Virtue" at the department of History, Stockholm University (2013-2016), funded by The Swedish Foundation for Humanities and Social Sciences (Riksbankens jublieumsfond). I would like to thank the participants in the pre-modern seminar at the department, and participants at the sixth Nordic Conference on Educational History (20-21 August 2015) for valuable feedback on an early draft of this text. All translations in this article are my own.

1 The sources for early education in the Classical world are limited, the most important being books I-II of Quintilian and On the Education of Children by (pseudo-)Plutarch. A classic, albeit idealistic, study of these ideas is Werner Jaeger, Paideia: The Ideals of Greek Culture, vol. 1-3, transl. Gilbert Highet (Oxford \& New York: Oxford University Press, 1965 [1939]). Teresa Morgan has shown how such educational ideals were (and were not) put into practice; Literate Education in the Hellenistic and Roman Worlds (Cambridge: Cambridge University Press, 1998).

2 In the primary sources used in this article, the education discussed must be presumed to be all-male. Other writers, notably Comenius, Didactica Magna, in Johannes Amos Comenius, Didactica Opera Omnia (Amsterdam, 1657), 42-44, did advocate education for girls as well. Schools for girls did exist in Sweden in the early modern period, but they were not publically funded, and information on them is scarce (see for instance Wilhelm Sjöstrand, Pedagogikens historia, II (Lund: Gleerups,

Andreas Hellerstedt is a PhD in the History of Ideas, Stockholm University, Sweden.

Email: andreas.hellerstedt@idehist.su.se 
habit. But this acquisition was not a creation ex nihilo. There was always some innate natural disposition, some basic intellectual capability necessary for achieving knowledge, just as there was an innate potential, the perfection of which Aristotle called virtue. ${ }^{3}$ In the seventeenth century, this innate potential was generally called ingenium.

The purpose of this article is to analyse a selection of texts discussing this problem of ingenium. I will try to situate these discussions within a social and political context in Sweden around 1680. I will investigate the following questions: how did Swedish academics of the period conceive the relationship between ingenium and virtue or knowledge? Which teaching methods did they advocate? What did their views entail for the role of education in society?

Methodologically, I will mainly use a contextual form of analysis, although the history of the concepts themselves and the philosophical tradition to which they belong will also be given due consideration. ${ }^{4}$ The material used for this study is a selection of dissertations published at Uppsala university from 1679 to 1685 . They represent a small selection from a larger corpus of dissertations on educational theory and practice from Swedish universities in this period. This corpus has been largely ignored by previous research on educational history. Furthermore, the three texts chosen for this study are particularly interesting for contextual reasons: both the professor and one of the students were engaged in practical teaching with special relevance for the issues discussed (see below).

Research on early modern educational history has often had a critical point of view, describing both early modern schools and society as institutions of social discipline. This research has been strongly influenced by the works of Michel Foucault. ${ }^{5}$ The humanist curriculum has also been criticised for being much less 'humanist' in practice than it was in theory, as the ideals of character formation and building of humanitas were seldom realised in classrooms dominated by tedious study of Latin grammar and style. ${ }^{6}$

1965), 136). In the dissertations analysed below, the question of female education is not discussed. It seems reasonable to assume that the texts take it for granted that what they are describing is an exclusively male form of education, even though this is not explicitly stated. The Swedish universities were of course all-male institutions until the nineteenth century.

3 Aristotle, Nicomachean Ethics (Cambridge, Mass.: Harvard University Press, 1934), 1098a7-17. The idea of perfection became perhaps even more important in the subsequent tradition, as in Aquinas and other scholastic philosophers, see (e.g.) John Finnis, Aquinas: Moral, Political, and Legal Theory (Oxford: Oxford University Press, 1998), 104-10.

4 For contextual analysis, see for instance, Quentin Skinner: "The essence of my method consists in trying to place such [historical] texts within such contexts as enable us in turn to identify what their authors were doing in writing them." Reason and Rhetoric in the Philosophy of Hobbes (Cambridge: Cambridge University Press, 1996), 7. For the history of concepts, see Reinhart Koselleck, "Begriffsgeschichte und Sozialgeschichte," in Vergangene Zukunft: Zur Semantik geschichtliche Zeiten (Frankfurt a. M.: Suhrkamp, 2015 [1989]), 107-9. I agree with Mats Persson that conceptual history can be useful as a complementary method in intellectual history, and I also agree with his criticisms of Koselleck, as put forward in "Begreppshistoria och idéhistoria," in Trygghet och äventyr. Om begreppshistoria, ed. Bo Lindberg (Stockholm: Kungl. Vitterhets Historie och Antikvitets Akademien, 2005), 14-34.

5 Some examples dealing with early Swedish material are Per-Johan Ödman, Kontrasternas spel: En svensk mentalitets- och pedagogikhistoria (Stockholm: Prisma, 1998); Daniel Lindmark, Uppfostran, undervisning, upplysning: Linjer i svensk folkundervisning före folkskolan (Umeå: Umeå University, 1995).

6 The groundbreaking study is Anthony Grafton and Lisa Jardine, From Humanism to the Humanities (London: Duckworth, 1986), which contrasts starkly with earlier accounts such as Eugenio Garin, 
On the other hand, the last 20 years have also seen a renewed interest in premodern philosophies of education, following a resurgent interest in virtue ethics. However, this interest has not always had a historical perspective, and very seldom has it had a critical one. ${ }^{7}$ In a previous work, I have proposed to combine a historical study of virtue ethics with Bourdieu's theory of habitus. Habitus is itself a concept which is ultimately derived from scholastic moral philosophy, and Bourdieu's use of it is well suited to an analysis of early modern educational theories situated in the context of teaching practice. ${ }^{8}$

The concept of ingenium has, for the most part, been studied by literary historians, often with an interest in the theories about genius that were later developed, at least in part, from this concept. ${ }^{9}$ In this article, I will instead consider the concept from the viewpoint of the history of education and moral philosophy. As will become apparent, ingenium was a concept of much wider significance than the later term "genius" had and has today. It was central to questions of education and the place of education in society, questions widely debated in the seventeenth century as a consequence of rapid changes in forms of and institutions for education all over Europe, including Sweden. Here, Gustavus Adolphus himself argued that "every ingenium should be allowed to excel in that towards which it is inclined." ${ }^{10}$

\section{Background: ingenium in the early modern period}

In the early modern period, Renaissance humanism often stressed the infinite malleability of man and the limitless possibilities of education. However, this much discussed Renaissance view of man competed with other, much more pessimistic conceptions of human nature. Even within Renaissance humanism itself, there were dissenting voices. ${ }^{11}$ Pessimistic views of human nature included those of the reformers, such as Luther, but also political thinkers such as Machiavelli and Hobbes.

Geschichte und Dokumente der abenländischer Pädagogik, I-III (Hamburg: Rowohlt, 1964-1967 [1957]). Incidentally, the findings of Grafton and Jardine are strikingly similar to those of Morgan (on the Classical material).

7 E. g., Martha Nussbaum, Cultivating Humanity: A Classical Defense of Reform in Liberal Education (Cambridge, Mass.: Harvard University Press, 1997); David Carr and Jan Steutel, Virtue Ethics and Moral Education (London: Routledge, 1999); Kristján Kristjànsson, Aristotelian Character Education (London: Routledge, 2015); Chris Higgins, The Good Life of Teaching: An Ethics of Professional Practice (Malden: Wiley-Blackwell, 2011).

8 Andreas Hellerstedt (ed.), Virtue Ethics and Education from Late Antiquity to the Eighteenth Century (Amsterdam: Amsterdam University Press, 2018), 17-19.

9 See Paula Gambarota, Irresistible Signs: The Genius of Language and Italian National Identity (Toronto: University of Toronto Press, 2011); Kristina Nordström, Det sanna snillet: Genus och geni hos Thomas Thorild (diss. Stockholm University; Göteborg: Makadam, 2014).

10 Karl Gabriel Leinberg, Om snillevalet (Selectus ingeniorum) i vår äldre skollagstiftning (Helsingfors: Finska litteratursällskapet, 1884), p. 6 notes that this discussion is visible from ca 1580 onwards, but otherwise focuses mostly on the eighteenth century; Sjöstrand (1965), 135-36, 184, 189, 204-5, 208, 232, 257-58; quote, "låta vart ingenium excellera i det som det inklinerar till" at p. 232.

11 Se for instance Paul Oskar Kristeller, Renaissance Thought and its Sources (New York: Columbia University Press, 1979), 169-181, Douglas Biow, On the Importance of Being an Individual in Renaissance Italy: Men, Their Professions, and Their Beards (Philadelphia: University of Pennsylvania Press, 2015), 57. Geoffrey Herman Bantock, Studies in the History of Educational Theory, vol 1 (London: Allen \& Unwin, 1980), 26. 
The discussion of variations in human talent (ingenium) can be traced back to antiquity. Roman rhetorician and teacher Quintilian discusses the relation between innate talent and acquired skill in his Institutio Oratoria, that is, in the context of rhetorical education. Some people obviously speak well without formal training, Quintilian says, so do we really need it? The answer to this question is balanced: nature is a prerequisite, and the speaker does not only need a talent for study, but also a strong voice and other natural abilities. However "this in itself does no good without a skilled teacher, persistent study, consistent and numerous exercises in writing, reading, and speaking." ${ }^{12}$ Quintilian admits that it is important for the teacher to observe the differences in talent (discrimina ingeniorum), as different boys are more or less suited to different types of study. However, because his ideal is an orator with an all-round education, a greek enkyklios paideia, this does not matter much: a good orator must learn everything, like the athlete in the pankration must know how to fight in every possible way. Everything which is perfected by art has its origin in nature, "but the most proficient [orators] owe more to instruction than to nature."13

Erasmus of Rotterdam is similarly optimistic. In the De Ratione Studii, he claims that he in a short time would be able to bring youths to a reasonable level of eloquence, if only they were not entirely lacking in talent. ${ }^{14}$ In De Pueris Instituendis, Erasmus describes man as created by nature for acquiring knowledge, and education as a source of both happiness and moral virtue. Although man's reason is a divine gift, God also "left the greater part to [be developed by] education." ${ }^{15}$ Most famously, Erasmus says: "believe me, human beings are not born, they are made." ${ }^{16}$ Erasmus, then, represents the optimistic view of education which was such an important part of the Renaissance. ${ }^{17}$ Erasmus's works, not least his mirror for princes, Institutio Principis Christiani, were very influential in the Scandinavian countries, his writings being some of the most important sources of Renaissance ideas in Northern Europe. ${ }^{18}$

The contemporary and friend of Erasmus, Juan Luis Vives, was one of the most important early modern figures to discuss the problem of ingenium. ${ }^{19} \mathrm{He}$ did so at

12 "haec ipsa sine doctore perito, studio pertinaci, scribendi legendi dicendi multa et continua excercitatione per se nihil prosunt." Quintilian, Institutio Oratoria (Cambridge, Mass.: Cambridge University Press, 2001), proemium, 27; also 2:13:15. I should also add that Baltasar Gracián's use of the concept of ingenium seems related to those discussed here, although Gracián's is highly idiosyncratic; Emilio Hidalgo Serna, "The Philosophy of Ingenium: Concept and Ingenious Method in Baltasar Gracián," Philosophy \& Rhetoric 13:4 (1980).

13 "consummatos autem plus doctrinae debere quam naturae," Quintilian (2001), 2:8:1-15. Enkyklios paideia, 1:10:1.

14 "modo dentur ingenia non omnino infoelicia," Erasmus Roterodamus, Opera Omnia, vol I:2, ed. Jean-Claude Margolin (Amsterdam: North Holland, 1971), 146.

15 "maximam partem reliquit institutioni," Erasmus (1971), 28.

16 "homines, mihi crede, non nascuntur, sed finguntur." Erasmus (1971), 31.

17 Bantock (1980), 54-55.

18 Andreas Hellerstedt, "Cracks in the Mirror: Changing Conceptions of Political Virtue in Mirrors for Princes in Scandinavia from the Middle Ages to c.1700," in Virtue Ethics and Education from Late Antiquity to the Eighteenth Century, ed. Andreas Hellerstedt (Amsterdam: Amsterdam University Press, 2018); Sebastian Olden-Jørgensen, "Hvad er et fyrstespejl?", in Johann Damgaard, Alithia: Et dansk fyrstespejl til Christian IV (Copenhagen: Museum Tusculanum Forlag, 2003); Sebastian Olden-Jørgensen, "Johann Damgaards Alithia (1597): Genrehistorie, teksthistorie og idehistorie: Omkring et dansk fyrstespejl til Christian 4.," Fund og Forskning i Det Kongelige Biblioteks Samlinger 45 (2006).

19 Hidalgo Serna argues that Vives, like Gracián, built a philosophy of ingenium. There is some truth in this, in my view, but Hidalgo Serna is slightly overstating his case. These ideas were widespread, 
length in De Tradendis Disciplinis, which took the discussion one step further. Vives argues unequivocally that different academic subjects require different mental abilities. These abilities depend fundamentally on temperament. Some people naturally have sharp observation, some have good judgement, some can distinguish different elements separately, some see things as a whole. Some have a well-balanced intellect, and can perceive everything correctly in one glance. But these different abilities are not always found in the same person. However, it is possible to determine what type of study is appropriate for each individual, and thus direct schooling accordingly, so that students are not forced to do anything against their inclination- "Minerva unwilling" ("Invita Minerva"). ${ }^{20}$ Vives goes on to describe how this may be organized in practice. He recommends that schoolteachers meet regularly to discuss their pupils' abilities and the direction their studies should take:

The boy should remain in the school for one or two months, so that his ingenium can be explored. Four times every year, the teachers should convene in a secret location, where they may speak and deliberate amongst themselves about the ingenia of their [pupils]: and they should apply each of them to that type of art, for which he seems fit. ${ }^{21}$

Vives recommends arithmetic in particular as a tool for revealing quicker or slower talents. ${ }^{22}$

Slightly less well known, but of major importance in the history of education, was Spanish medical doctor Juan Huarte's argument in Examen de ingenios para las sciencias $(1575)^{23}$ that education should be adapted wholly after innate individual and national characteristics resulting from differences in bodily temperament. He bluntly argued that it was impossible for a man to excel in more than one area, and that it was imperative that everyone find the occupation towards which they were "aptum natum." ${ }^{4}$

As Henning Mehnert has shown, the "deterministic humoralism" of Huarte was attacked by Jesuit educational writers towards the end of the seventeenth century. These writers refused to reduce man to a product of mere physical preconditions. ${ }^{25}$ Among the most prominent of the opponents of Huarte was the Jesuit Antonio Possevino, who, among other things, was the papal diplomat assigned with the (failed)

had roots in Classical rhetoric, and were not incompatible with scholastic Aristotelianism. Compare Emilio Hidalgo Serna, “Ingenium' and Rhetoric in the Work of Vives," Philosophy \& Rhetoric 16, no. 4 (1983).

20 Juan Luis Vives, De Tradendis Disciplinis, in De Disciplinis Libri XII. Septem de Corruptibus Artibus; Quinque de Tradendis Disciplinis (Leiden, 1636) 406-7, 437, 448-58; Erasmus (1971) also admits that pupils should not be forced "adversus Minervam," "invita Minerva," 45, 67.

21 "Maneat puer in pedagogio unum aut alterum mensem, ut ingenium illius exploretur. Quarter per annos singulos in locum aliquem secretum magistri convenient, ubi inter se de ingeniis suorum sermonicentur, ac consultant: \& ei quenque applicent arti, cui quenque idoneum videbunt." Vives (1636), 437.

22 Vives (1636), 458.

23 Translated into latin as Scrutinium Ingeniorum pro ijs, qui Excellere Cupiunt (I have used the edition of Leipzig, 1622).

24 Huarte (1622), 3; he did admit that more than one type of ingenium could be combined in one man, although this meant that they would not be "emine[n] te in gradu," 8.

25 Henning Mehnert, “Der Begriff 'Ingenio’ bei Huarte und Gracián,” Romanische Forschungen 91, no. 3 (1979), 274. 
task of reuniting Sweden with the Catholic Church in the 1570s. Later on, he worked actively to build Jesuit schools in Poland. In his Cultura Ingeniorum, Possevino argued from a premise of human dignity informed by Counter-Reformation Catholicism and Renaissance humanism. He describes the search for truth as the most worthy of pursuits leading to the highest virtue and bringing man closer to God. ${ }^{26}$ While admitting that it is important to understand that individual talents vary and to direct schooling accordingly, he argues for a form of equality on religious grounds. God grants everyone the capacity they need to fulfil their duties in whatever walks of life they find themselves. God does not grant everyone everything, but neither does he exclude anyone from free will and the path to salvation. ${ }^{27}$ In particular, Possevino argues directly against Huarte (and in more secular terms) that skills in language and "speculative science" are often found in one and the same individual. Where Huarte had claimed that Spaniards could not learn Latin well because their natural ingenium was suited for theology but not language, Possevino argued that Spain simply lacks proper schools and that Spaniards just do not study hard enough, while also providing historical examples of individuals of Spanish descent who were skilled in both areas. ${ }^{28}$ Similarly, another great educational reformer of the age, Johann Amos Comenius, argued that everyone should basically receive the same education (he famously argued that everyone should learn everything), but that different types of talent require different forms of education, or different teaching methods. ${ }^{29}$

Rebecca Bushnell has argued that Renaissance humanism neither tried to shape every individual into one universal ideal humanity, nor did it claim that we are all unique individuals. Instead, humanism commonly identified different "types," and in doing so could work to "reify" differences (of estate, gender, age, etc.) and reinforce social hierarchies, while she also admits that the teacher's power over his students was limited. The fact that the individual nature was thought of as resisting the teacher's efforts could therefore work as a form of resistance to power as well. ${ }^{30}$ However, as we have seen, the differences between individual theories were significant: humanism was not a uniform movement. There was also development over time, as determinism gained ground during the sixteenth and seventeenth centuries. ${ }^{31}$ Consequently, the seventeenth century inherited an intricate problem in educational theory. What was the balance of power between inherited talent and acquired skill and knowledge? And how exactly was raw talent (ingenium) developed into skill and moral virtue?

26 Antonio Possevino, Cultura Ingeniorum: Examen Ingeniorum Ioannis Huartis Expenditur (seventh edition, Cologne, 1610), 10-12; Possevino uses language reminiscent of Pico della Mirandola's Oration on the Dignity of Man in describing man as positioned in the center of the world, free, and not far below the angels (p. 12); Interestingly, Comenius (1657), chapters 1-6, also starts off with similar statements on the dignity of man (to be fulfilled through education), man as the crowning glory of creation, etc.

27 Possevino (1622), 34-35, 42.

28 Possevino (1622), 50-51, 55-56. In another context he concedes that Italians are characterised by their extraordinary "judicium," the Spaniards on the other hand by their "alacritas ingeniorum \& gravitas," only to counter this with the impeccable statement that one observes in all of them the same great piety; 138 .

29 Comenius (1657), 44-48.

30 Possevino (1622), 114-17.

31 Mehnert (1979), 271-72. 


\section{The Swedish context}

The material I will study needs to be put into a more immediate context. Seventeenth century Sweden was characterized by a societal structure somewhat different from other European countries at the time. The free peasants were numerous and they were represented in the Riksdag (parliament). They were in a (relatively) strong political position. Furthermore, the nobility, while at times very strong politically, were too few to monopolize all posts in the bureaucracy and officers' corps. With the rapid expansion of a modern state, and with accompanying demands for professionally trained jurists and civil servants, the seventeenth century opened up many opportunities for well-educated men of non-noble origins. Among those who took advantage of such opportunities, most had their roots in the burgher estate, while sons of prosperous peasants would more often advance socially through the church. A few made spectacular careers. Among them we find a number employed as royal tutors. Johan Skytte, the son of a burgomaster, became the preceptor of Gustavus Adolphus and was made a baron; Edmund Figrelius (ennobled as Gripenhielm), the son of a pastor, was a professor at Uppsala and a diplomat and secretary in the service of Charles X, and became the preceptor of the crown prince (Charles XI); Gripenhielm's disciple at Uppsala university, Erik Lindeman (Lindschöld), like Skytte the son of a burgomaster, was the preceptor of the illegitimate son of Charles $\mathrm{X}$ before he became the governor of another crown prince (Charles XII) and was made a count; Nils Gyldenstolpe, who replaced Lindschöld as governor, was the son of professor Michael Wexionius (ennobled in 1650). ${ }^{32}$

Andreas Norcopensis, the praeses (i.e. chair or supervisor) of the dissertations analysed here, had a similar background to the men given as examples above. Nordenhielm, as Norcopensis was known after his ennoblement in 1686, is famous in Swedish historiography as the preceptor of the crown prince Charles (subsequently king Charles XII). He worked under the direction of the prince's governor, the aforementioned Erik Lindschöld. The educational material Nordenhielm and the prince used are equally famous. Just as Johann Amos Comenius suggested in Orbis Sensualium Pictus, Charles drew pictures of animals and wrote their names in Latin and Swedish beside them. ${ }^{33}$ Nordenhielm was provided with a detailed Instruction $(1690)^{34}$, held to be the work of Erik Lindschöld. Comparing the dissertations with this instruction provides an opportunity to study educational ideas of the period in some detail, and in close connection to contemporary educational practices of very different kinds.

As professor at Uppsala, Norcopensis presided over a large number of dissertations (88). The subjects range from the nature of sound to suicide ${ }^{35}$, but issues of

32 Andreas Hellerstedt, "Praeses and Praeceptor: A Late 17th-Century University Dissertation as a 'Mirror for Princes"', in Early Modern Academic Culture, ed. Bo Lindberg, KVHAA Konferenser, 97 (Stockholm: Vitterhetsakademien, 2019).

33 Kungliga Biblioteket, Stockholm, MS KB D761 (Notes of the crown prince Carl and his teacher Nordenhielm from the years 1688-1692); Johann Amos Comenius, Orbis Sensualium Pictus, ed. Lars Lindström (Stockholm: HLS Förlag, 2006), 21.

34 Kungliga Biblioteket, Stockholm, MS KB D 730: INSTRUCTION Huru then Kongl: Maij $\beta$ : Troo Man och Secreterare af Staten sampt hans Kongl: Högheetz, Printz CARLS Praeceptor, Edell och Wällbördig Andreas Nordenhielm uthj hans Kongl: Höghetz Uptuchtelse och Undervijsning sig hafwer ath rätta. Gifwen STOCKHOLM d 29 Martij Åhr 1690.

35 See Peter Sjökvist, The Music Theory of Harald Vallerius: Three Dissertations from 17th Century 
moral philosophy and politics are most common. Questions of education also feature quite prominently, and can be seen as a natural part of the chair of rhetoric which Norcopensis held. The three dissertations studied here are thus only a part of a larger number of texts, including titles such as De Academia, Phoenix et Achilles, etc. The texts I have chosen are entitled De Educatione Liberorum (On the education of children), De Praeceptore et ejus Officio (On the teacher and his duties) and De Modo Acquirendi Virtutes (On how to acquire the virtues). ${ }^{36}$

\section{Virtue ethics and ingenium}

Despite covering slightly different topics, the three texts share many common ideas and viewpoints. Most importantly, two key concepts, or rather two clusters of concepts, are central to them. The first of these is the system of Aristotelian virtue ethics, which still influenced university teaching on moral philosophy in Sweden in the late seventeenth century. ${ }^{37}$ The second is a less systematic set of ideas about human ingenium, which has been outlined above. These two sets of ideas represent opposites within human nature, such as it was conceived at the time. Virtue was those character traits or dispositions which we acquire, and thus represent our potential for improvement, or even an ideal humanity. It is the optimistic side of seventeenth century anthropology. Ingenium, on the other hand, was that which we cannot change, our natural pre-disposition. In that sense it was more negative, as it represented the limitations of mankind, and of the individual.

Douglas Biow has recently re-examined the classical issue of notions of the individual in the Renaissance and he turned his attention to the importance of notions of that special something, the extraordinary talent, which (in their own eyes at least) distinguished famous artists, writers and other professionals during that period. It served to make them unique individuals:

\footnotetext{
[...] a number of the practitioners who turned to authorship in the Italian Renaissance were keenly aware that some people will be good at acquiring an art and some people will not, so that no matter how hard or diligently they work at it, an innate magical something, the mysterious raw talent of "ingenium," was ultimately required to allow a person to make that leap from being a dutiful learner to becoming a remarkable practitioner within a profession. ${ }^{38}$
}

Sweden (Uppsala: Uppsala University, 2012); Erland Sellberg, "Berömmelse i döden: Om det rationella självmordet," in Utopin i vardagen: Sinnen, kvinnor, idéer: En vänbok till Elisabeth Mansén, ed. Jenny Leontine Olsson, Anna Ohlsson, Ylva Söderfeldt and Jonas Ellerström (Lund: Ellerströms, 2014), 235-60.

36 Andreas Norcopensis/Carolus Malmenius, De Educatione Liberorum per Tres Priores Aetates (pro gradu; Stockholm, 1685), Andreas Norcopensis/Johannes Krutenius, De Praeceptore et ejus Officio (pro gradu; Uppsala, 1681a), Andreas Norcopensis/Jonas Bierchienius, De Modo Acquirendi Virtutes (pro gradu; Stockholm, 1679). They also share many ideas with other of Norcopensis' dissertations which I have studied in Hellerstedt (2018b) and "The Absolute Hero - Heroic Greatness and Royal Absolutism in Sweden 1685-1715," in Shaping Heroic Virtue: Studies in the Art and Politics of Supereminence in Europe and Scandinavia, ed. Stefano Fogelberg Rota and Andreas Hellerstedt (Leiden: Brill, 2015).

37 Bo Lindberg, "Virtue and Duty: Academic Moral Discourse in Seventeenth Century Sweden," in Virtue Ethics and Education from Late Antiquity to the Eighteenth Century, ed. Andreas Hellerstedt (Amsterdam: Amsterdam University Press, 2018).

38 Biow (2015), 86. 
The university dissertations proceed from the then commonly held view of human life as divided into seven separate ages. Of these, the three earliest are relevant to questions of education: infantia (from birth to ca 7 years of age), pueritia (ca 7-14), and adolescentia (ca 14-25). De Educatione makes it clear that this division is not universal among pedagogues. Using it seems to be motivated more by pragmatism (it was the most well-known division of human life familiar to the audience and readers). The tri-partite division is coupled with an idea of a progressive differentiation of education, because each stage has its own particular ingenium, to which the teacher must take due consideration. Thus, it is the second age "which brings with it those powers, which can respond to the efforts of teaching," although it is also stressed that it still is very important to respect the tenderness of this age. ${ }^{39}$ The ideas on the specific nature (ingenium) of the different ages of man are similar to those of both John Barclay and Comenius, although none of them uses a seven-stage division. Barclay divides man's life into four stages (youth being divided in two, pueritia and adolescentia), while Comenius divides youth into no less than four stages, with corresponding schools: Gremium Maternum, Ludus Literarius (Schola Vernacula), Schola Latina (or Gymnasium) and Academia (including peregrinationes); thus Comenius uses the same terms as the dissertation mentioned above, but adds juventus as a final stage following adolescentia. ${ }^{40}$

It is well-known from studies of early modern school practice that discipline was often harsh. ${ }^{41}$ There are also many examples of such discipline being strongly favoured in literature on education and the up-bringing of children in the early seventeenth century. ${ }^{42}$ The foundation for this reasoning was to a large part the theological dogma of original sin. In the three Norcopensis-dissertations, we encounter quite a different standpoint, although man's fallen nature is not in any way denied. This is in line with many humanist educators, such as Quintilian and Erasmus, who both argued against the use of physical violence. ${ }^{43}$

In De Educatione we read that studies (literae, studia humaniora) can be toilsome and sometimes boring, especially for those who are not accustomed to them. But this only means that teaching should be practiced using "play and enjoyment" ("lusu \& oblectatione") rather than "harsh punishment" ("dura castigatione"). This will attract the students towards their studies rather than fill them with disgust for them. This view may be borrowed from Comenius' Didactica Magna, although this is not

39 "[...] haec aetas eas secum afferat vires, quae discendi laboribus respondere possint [...]," Norcopensis (1685), 20.

40 A much more ambitious dissertation for which Norcopensis was the praeses, Gubernacula Imperii Togati, includes several references to Barclay's Icon Animorum; Andreas Norcopensis/Hemming Forelius, Gubernacula Imperii Togati. Ex Flor. lib. I. cap. 2. \$. 4. [...] (Stockholm, 1681b); John Barclay, Icon Animorum or The Mirror of Minds, ed. Mark Riley (Leuven: Leuven University Press, 2013), chapter 1; Comenius (1657), 165; Possevino also describes different classes and teachers suited for students of different abilities, Possevino (1622), 111.

41 Ödman (1998).

42 Englund, "Böj ditt barns hals: Adlig barnuppfostran och skolning under stormaktstiden," i Barn $i$ slott och koja (Skövde: Västergötlands turistråd, 1986), especially 47-50; Englund focuses on education among the nobility, and adds only in passing that new educational ideas challenged the older strictness, a strictness which Englund connects with the reformation.

43 E. g. Quintilian (2001), 2:4:10; Erasmus, De Pueris, Erasmus (1971), 54-63. 
acknowledged. In fact Comenius is never mentioned. ${ }^{44}$ The idea to make studies more appealing using games was common in the humanist tradition. It was closely related to the question of individual ingenia. Similar expressions are also found in Possevino (who is referenced), who wishes that " $\&$ lusus ipse eruditio sit" by the use of letters of wood such as St. Jerome advocated, and that other "honest amusements" ("jocis honestis") should be used which excite the pupil's talents ("excitentur ingenia"). ${ }^{45}$ Indeed, the idea that play or games could be a part of education can be found in several Classical and Renaissance educational writers. Plato seems to advocate play in education in Laws 643B-C. Quintilian presents his teaching methods as a form of lusus several times. ${ }^{46}$ Vives says that while play (ludus) is a form of recreation, it can also be used for educational purposes: "they should speak Latin when playing, and according to the rules of the game, penalties should be incurred for those who speak in their mother tongue." ${ }^{37}$ However, Comenius systematised the idea that learning should take the form of a game, especially in Schola Ludus, a collection of constructed dramatical dialogues. The prologue to that work is in effect a treatise on the school as play or game. In this work, Comenius wishes to show "how all schools can be turned into play." ${ }^{8}$

This is also true of the Instruction for the crown prince's education, in which the teacher is similarly advised to plant a desire for learning languages in the prince. To avoid letting him get fed up with Latin grammar, "Tabulae compendianae" should be used. The preceptor should see to it that the prince always has "Tabulas Chronologicas and Geographicas" in his chambers, so that he may learn geography "as if by playing." ${ }^{49}$ Both the Instruction and De educatione as a whole, however, argue for striking a balance between on the one hand too strict and harsh forms of discipline, and on the other an excess of love, which only nurtures vice. ${ }^{50}$

The thesis put forward by Vives and Huarte, that individual talent should determine academic specialisation, was very influential in seventeenth century Europe. It is clear that this view is well known by the authors of the dissertations. They stress that it is important to observe the specific talents of the students and their natural inclinations ("ingenii dona, animique naturales propensiones"), as these vary very much from one individual to another. The teacher is advised to first examine the "disease" and its causes before he administers his medication, just like a physician: the teacher should examine the ingenia of his students and entice the power of their talent before he begins teaching them. ${ }^{51}$

44 Norcopensis (1685), 20-21. Comenius, Didactica Magna, in Comenius (1657), 79, 83.

45 Possevino (1622), 76, 91, (quotes at p. 76). Quintilian has letters of ivory, Quintilian (2001), 1:1:26, Erasmus, De pueris adds cakes baked in the form of letters, which the pupils can eat, Erasmus (1971), 70 .

46 Quintilian (2001), 1:1:26; also 1:1:20, 1:1:36, 1:3:10-11; Erasmus develops the same idea in De pueris, Erasmus (1971), 66-73.

47 "Latine inter ludendum loquentur, statuta illi poena ex ratione ludi, qui patrio sermone erit usus." Vives (1636), 503.

48 "Quomodo Scholae omnes in Ludos verti possent." John Amos Comenius, Schola Ludus, in Comenius (1657), [viii-ix].

49 Instruction, 14, 16, 18. The Instruction shows many similarities to Erasmus, De Ratione Studii in particular.

50 Norcopensis (1685), 31-32, 33-36. Possevino (1622), 97-98 also advocates a "mediocritas" of freedom, although perhaps more from fear of heresy (a fear that permeates that work).

51 Norcopensis (1681a), 11-12. 
The starting point, in other words, is the distinction between the gifts with which we are born and the knowledge and skills we acquire during the course of our lives. After the fall, man is like a ship without a captain: we are unable to control our desires. Within man a battle is being fought between reason and "our depraved desires." ${ }^{2}$ This battle is particularly intense during youth. Children and adolescents do not understand their own good and are naturally inclined towards evil, the dissertations state. $^{53}$ This sentiment is clearly reflected in the Instruction as well. In fact, young princes are even more prone to give in to the temptations and weaknesses of youth, as a result of their exposed position. ${ }^{54}$

Education, however, can work as a counterweight, balancing the limitations of man's (evil) nature. Interestingly, the dissertation De Educatione develops this position using arguments from natural law, with a direct reference to Pufendorf's De Jure Naturae et Gentium (published in Sweden in 1672). Parents are obliged by the law of nature to care for their children, and thereby save them from the misery of their natural state, it is argued. ${ }^{55}$ The result of the counterbalance is virtue, in turn defined in commonplace fashion as mastery of the passions through the exercise of reason, as explained in De Educatione, ${ }^{56}$ and developed at length in De Modo Acquirendi Virtutes. One's actions should be directed by recta ratio, that is, adhere to the right measure or mean, whereby the passions are held in check. ${ }^{57}$

According to the dissertations, a "seed" of virtue is considered to remain in man, despite the inherent depravity (pravitas) of mankind after the fall. This seed is the material with which education has to work. Like man's natural sinfulness, the seed of virtue is something with which we are born ("a nativitate inhaerentia"). It is what makes us able to distinguish good from evil. However, this ability is severely diminished (by original sin), and seldom bears fruit without being awakened by an appropriate education ("commoda excitentur educatione"). ${ }^{58}$

The plant metaphor often associated with Aristotelian virtue ethics ${ }^{59}$ is prominent in all the dissertations as well as the Instruction. Education is cultivation: if the seed is not sown in good, well-worked soil, and the plant not watered, it will fail. A description gathered from Pseudo-Plutarch is only one of several variants of this metaphor: as in agriculture, where not only seeds, but good soil and a skilled farmer is needed, virtue requires a good nature (in the student), a good teacher, and good precepts. ${ }^{60}$ In this particular version, the seeds are the precepts, and not the good nature of the student. In fact, seeds, soil and hard work seem to be thought of as being

52 Norcopensis (1685), 3.

53 Norcopensis (1685), 3-4, 12-13, Norcopensis (1681a), 3.

54 "många wägar och tillfällen [...] thärigenom förnähme Herrars, och serdeles Furstars och Konungars barn kunna blifwa förledde och utj sine unga Åhr brachte till Öfwermod och Egensinnigheet [...]," Instruction, 2-3.

55 Norcopensis (1685), 13-15; the reference is to Samuel Pufendorf, De jure naturae et gentium libri octo (Lund, 1672), 4:2, \$4.

56 With a quotation from dutch philosopher Adrianus Heereboord's (1614-1661) ethics reason is described as a king, against whom desire rebels. Norcopensis (1685), 5.

57 Norcopensis (1679), 11-14.

58 Norcopensis (1685), 5.

59 Hellerstedt (2018a); see also Comenius, Didactica Magna, in Comenius (1657), chapter 5.

60 Norcopensis (1679), 6; similar wording in Norcopensis (1681a), 2. 
required in both student and teacher. As we will see, virtue and ingenium are just as important in the teacher as it is in the student.

It is also important to begin early, as children are particularly malleable and impressionable. With a Swedish proverb, the necessity of laying the foundations at an early age is stressed. The child is like a young plant, which is best formed as it shoots from the root: "Bend the branch while it is still pliable." ${ }^{61}$ The notion that children and adolescents are particularly impressionable is founded on Aristotelian epistemology and Galenic theory, both of which were commonplaces at the time. ${ }^{62}$ From Aristotle comes the notion of the human soul as a "tabula rasa" - a term which only later became associated with John Locke's philosophy. Aristotle's view was similar, but in many ways also more complex than Locke's. Aristotle was, to an extent, an empiricist. Man gains knowledge from the generalization from sense experience. When Comenius uses Aquinas' expression "there is nothing in the intellect which was not first in the senses," it is this Aristotelian form of empiricism he is associating himself with. ${ }^{63}$ Of particular interest to the present context is the way in which the sense information is thought to be impressed on us. The choice of the wax tablet-metaphor is no coincidence; in fact, it gives an important clue to how sense perception and understanding are thought to work in this paradigm. If the modern (Descartes' or Locke's) views primarily consider sense perception and ideas to be a question of images (in our mind), Aristotle seems to think of perception, at its most basic level, as a kind of touch. Furthermore, sense organs become "like" the object perceived in the process of perception: they receive the forms of objects, but not their matter. Thus, in my view, it helps to take the image of the wax being impressed upon by an external object quite literally. This metaphor seems to be relevant to much more than just the issue of sense perception, or even epistemology. In fact, in De Anima, Aristotle describes the unity of soul and body (form and substance) as such as the unity of the shape of wax and the wax itself. ${ }^{64}$

The wax-metaphor needs some qualification. In the dissertation De Educatione this is done by building on the modern Dutch philosopher Heereboord. Using Aristotelian terminology, the dissertation stresses that man is born with certain basic mental capabilities; we are not in a simple way a clean wax-tablet. Instead we have a potential, which needs to be actualised through the use of our intellectual faculties, and it is only "[...] in this respect of actual cognition, in which the soul is called an erased tablet [...]" ${ }^{35}$

61 "Wridh wedian medan hon är miuk." Norcopensis (1685), 23; this is very similar to Erasmus, De Pueris; Rebecca W. Bushnell, A Culture of Teaching: Early Modern Humanism in Theory and Practice (Ithaca and London: Cornell University Press, 1996), 95.

62 Norcopensis seems to have been quite open to new ideas, such as those of Descartes, whose system was surrounded by a great deal of controversy in late seventeenth century Sweden; see Sjökvist (2012). In the dissertations on politics and moral philosophy I have studied however, there are no significant traces of Cartesian philosophy.

63 The expression is found in the preface to Comenius's Orbis (original German edition of 1658); Comenius (2006), 18.

64 Thomas J. Slakey, "Aristotle on Sense Perception," The Philosophical Review, 70, no. 4 (1961), 47084. Pseudo-Plutarch, The Education of Children, 3e-f, Moralia, vol 1 (Cambridge: Harvard University Press, 1927) uses a similar image and Possevino (1622), 75 uses the wax metaphor as well, as does Erasmus, De Pueris; Bushnell (1996), 95-96.

65 "[...] hujus actualis cognitionis respectu, anima dicitur tabula rasa [...]," Norcopensis (1685), 6-7. 
The characteristics of the matter which education seeks to shape are not unimportant. However, it is not because the child is matter without form that it is receptive to education. That would, strictly speaking, be impossible. Aristotelian psychology explains why man in general is dependent on the senses for knowledge. The Galenic theory of the four humours provided the explanation as to why children are particularly impressionable. Children were thought to be characterised by a cold and moist temperament, and consequently they were soft and malleable. With age, man would dry up and harden. ${ }^{66}$ The fact that children are impressionable and malleable in this way is apparently something of a double-edged sword. It does facilitate learning, but it also makes young minds particularly receptive to vice and sin. Coupled with long standing Christian teachings on original sin, it is not surprising that children were considered more receptive to negative impressions. ${ }^{67}$

But it is clearly not only a question of preventing moral vice. To awaken the student's talent (his ingenium) is considered important in the Instruction for purely intellectual reasons as well. In his exercises with the prince, Nordenhielm is instructed to see to it that he constantly discusses and reflects on the texts read "so that [his] ingenium and judicium may thereby be sharpened and awakened." ${ }^{8}$ Consequently, the aim of education is to put this innate foundation in a correct form of activity, to awaken or entice those gifts of nature which are there, as it were, sleeping, in man. ${ }^{69}$ We do not achieve virtue from nature unaided, but through "daily habituation, frequent exercise"; as habit of course is as a "second nature."70

This means that whoever wishes to excel in something, whether it be mathematics, logic, drawing or military bravery, should exercise his ingenium in those actions, which result in a stance (habitus) corresponding to that particular virtue (or skill). Those who wish to be brave should simply perform brave actions: "For such as the actions are, so will the stance generated by them be: from good actions a good stance, from bad actions the opposite." In short, habituation (assuefactio) is the immediate cause of virtue. Because this means a frequent repetition of morally righteous actions, learning and education should be directed towards this purpose. ${ }^{71}$ It is difficult to determine exactly how many actions are sufficient to obtain virtuethis varies according to the individual's ingenium - but a person who abstains from bodily pleasures gladly is clearly temperate, while the person who does so only with pain is still intemperate; a forced virtue is no virtue at all. ${ }^{72}$

This view, then, seems to underline the need for repetition. To modern eyes, it might seem odd that moral goodness should be taught in the same way as playing an instrument or learning to write, but such metaphors are very prominent in the material. In fact, Julia Annas, a philosopher and expert on Classical virtue ethics, has taken up this point as characteristic of virtue ethics, calling it the "skill analogy."

66 Possevino (1622), 34-35.

67 Norcopensis (1681a), 5.

68 “så att ingenium och judicium därigenom må hwässas och upwäckas," Instruction, 22.

69 Norcopensis (1685), 7.

70 Norcopensis (1685), 9, 31, 25; Norcopensis (1679), 5.

71 "Quales enim sunt actiones, talis inde generatur habitus, à bonis quidem bonus, à malis autem contrarius.” Norcopensis (1679), 10.

72 Norcopensis (1679), 14-15. 
However, Annas also points out that virtue-as-skill in this sense does not exclude intellectual reflection. ${ }^{73}$

In more general terms it may be expressed like this: the goal of education is to awaken the pupil's intellectual capacities and thereby make possible the reign of right reason over the passions. Furthermore, wisdom is in itself one of the virtues, but the individual virtues are dependent on one another. A learned man without good morals is like a soldier without a sword, and such learning is like an empty treasure chest. $^{74}$

\section{Education in service of the state}

Despite the lofty declarations of education as a shaping of moral virtue, the education discussed in these texts is legitimated through utility for the state. ${ }^{75}$ This is hardly surprising when considering the context in which they were written. The period in question coincides with the introduction of absolutist rule in Sweden (traditionally dated to 1680). The development of the early modern state with a concomitant increase in legislation, professionalised and expanded bureaucracy, and a general trend of regulation and intervention, not least into the private morality of individual subjects, is a common theme in seventeenth century historiography. ${ }^{76}$ The authors of these dissertations repeatedly underscore the need for education in appropriate political virtues. The person who will be serving the fatherland must have experience and be trained in political prudence. But the relation is also the reverse: in yet another Aristotelian echo, the state is described as a seminarium in the original sense of the word (nursery garden, seed bed). For it is the state which enables the growth and flourishing of virtue. ${ }^{77}$

The dissertations point out that the raw material is not evenly distributed among the subjects, but it is of the utmost importance that the state makes the most of them. Thus, human ingenia are a resource, which the state must exploit. However, it cannot be harvested if it has not been well cultivated, and so the state must nurture and care for this resource if it wishes to benefit from it. And this requires knowledge of these talents. The role of the teacher as a talent scout thus becomes an important one. It is during adolescence (adolescentia, 14-25 years) an assessment can be made of individual ingenia, and it is possible to make the adolescents choose those studies to which nature leads them, "because nature is its own judge" as one of the dissertations

73 Julia Annas, Intelligent Virtue (Oxford Scholarship Online, 2011), especially chapter 3.

74 Norcopensis (1985), 25-26. This echoes Quintilian (2001), proemium, 9, 13, 18.

75 As is often the case in this period, it is difficult to distinguish between what we in modern terms would call state and society; most often, res publica can be interpreted as being both, which is also in line with then-current political theories, such as Pufendorf and Hobbes, both of which were used by Norcopensis (see for instance Norcopensis (1681b)).

76 Significant studies on this subject include Sven A. Nilsson, De stora krigens tid: Om Sverige som militärstat och bondesamhälle (Uppsala: Uppsala University, 1990), Jan Lindegren, "Den svenska militärstaten," in Magtstaten i Norden i 1600-tallet og de sociale konsekvenser, Rapporter til den XIX nordiske historikerkongress Odense 1984, bind 1 (Odense: Odense Universitetsforlag, 1986), and more recently, Joachim Scherp, De ofrälse och makten: En institutionell studie av riksdagen och de ofrälse ståndens politik i maktdelningsfrågor 1660-1682 (Stockholm: Stockholm University, 2013).

77 Norcopensis (1685), 8-11 and 23-24. 
interestingly puts it. ${ }^{78}$ This is why parents who force their children to certain studies make a grave mistake, if this is done, as the saying went, "invita Minerva." "For as talents are different, so talents are also differently inclined." 79 One talent is appropriate for service within the church, another for the civil service, one for war, another for peaceful studies, one for music, another for crafts or manual arts, and so on. Each of them should be directed towards that which his nature inclines him to: "For whoever follows the inclination of his nature performs his duties successfully."

There are certainly those who should be dissuaded from school and academic studies altogether, but this is only proper for those who show "obvious signs of stupidity and difficult talent." ${ }^{\prime 1}$ This is important, because some show a slow and tardy ingenium to start with, but are able to improve themselves significantly and should therefore be handled with patience, so that they do not lose hope. Even those who may not have what it takes to reach the very summit of learning may at least do better. Furthermore, those who have a strong desire for studies may, despite being somewhat slow, compensate for what nature has denied them through hard work. ${ }^{82}$

These differing talents are also important in understanding virtue ethics. We have seen how man was considered to be born with a certain individual nature or talent, but that he must also cultivate this nature through training, habit, education. Which of these is more important is still unclear. And how exactly does this happen? First, it is stated repeatedly that "some claim" that virtue is given once and for all by nature. This view is at one point connected to the stoics, perhaps not entirely fairly. ${ }^{83}$ It is likely that this discussion rather aims at those debates that were so important during the beginning and middle of the seventeenth century, when virtue was discussed in connection with the legitimate grounds for noble status. ${ }^{84}$ The dissertations do not give any support to the view that there is any form of natural inequality, for instance among the estates. This is entirely in line with modern natural law, as in Pufendorf or Hobbes, according to whom estates would be an artificial institution, and not natural. Thus, it is claimed that virtue is not a direct consequence of our nature (our temperament). However, this nature does incline us towards certain virtues and vices, makes us suited for learning certain things, and so on. ${ }^{85}$

This does not mean that some are good by nature, while others must struggle to be so. On the contrary, it is those who have the most extraordinary gifts and sharpest talent who have the greatest need for education. Just like the fattest soil can be overgrown with weeds if neglected, an extraordinarily talented individual will turn into the worst kind (of sinner) if his education is neglected. The good man can be better,

78 “quoniam natura sui ipsius est iudex," Norcopensis (1985), 27.

79 "Ut enim varia sunt ingenia, ita ad varia propendent." Norcopensis (1685), 27, Norcopensis (1681a), 12.

80 "Quisquis autem sequitur inclinationem naturae suae, is felicius negotium absolvit." Norcopensis (1685), 27-28, quote, 28.

81 “aperta stupiditatis \& ingenii difficilimi signa," Norcopensis (1679), 15, similarly also, p. 12.

82 Norcopensis (1679), 15-16; Possevino (1622), likewise recommends patience with those who are slower, 92.

83 Norcopensis (1681a), 5, 9.

84 Discussed at length in Peter Englund, Det hotade huset: Adliga föreställningar om samhället under stormaktstiden (Stockholm: Atlantis, 1989).

85 Norcopensis (1681a), 4. 
but the one who is not so excellent can be corrected and sharpened by education. ${ }^{86}$ Clearly, the reasoning is the same whether the issue is acquiring knowledge or moral virtue; the processes hardly seem distinguishable at all. It is in our power to develop the seeds we possess through our bodily temperament, even though that temperament as such cannot be changed.$^{87}$ Once again it seems that an optimistic view of human nature co-exists with the Lutheran doctrine of man's sinfulness. What is perhaps more worthy of note, however, is the fact that the Galenic medical system seems to be at least as important here. The medicalisation of education is the most distinctive feature of this discussion. ${ }^{88}$ It also seems that this view of individual talent lends itself to an elitist interpretation, although this is an elitism based on individual talent rather than profession, wealth, inheritance, or social status.

It is interesting to consider the question of the education of kings against this background. Similar ideas on the student's individual ingenium can be found in the Instruction, as has already been noted. In contrast to contemporary panegyric, extraordinary intellectual talents are by no means taken for granted in the royal student. On the contrary, it is evident that the document considers the possibility of a prince struggling with those academic studies that he by this time had to undertake to manage the duties of a modern absolute monarch. As has already been mentioned, the preceptor is repeatedly admonished to ensure that the royal student is not bored and tires of his studies. Nordenhielm is to direct the prince's studies "according to his condition, and the nature of the high office," but also so as to avoid "the boredom and disinclination for studies, which might easily creep into the mind of His Royal Highness, if one were to burden him too much at first with such unpleasant grammatical exercises instead of pleasant, enjoyable, and useful historical tales" such as children in general, and the prince in particular, prefer. ${ }^{89}$ Such historical studies should be led by the preceptor in such a way that they may "be held to be a play and enjoyment" by the crown prince. ${ }^{90}$

\section{The teacher's ingenium}

So far, we have considered the views on education in these dissertations mainly from the viewpoint of the student. They have much to say about the teacher as well. In doing so, they tell us that university education could occasionally be quite close to professional teaching practice in the seventeenth century, even though this was perhaps not normally the case. De Praeceptore was defended by the student Johan (Johannes) Krutenius, who according to the title page was "Scholae Trivialis conrector designatus."

86 Norcopensis (1681), 8-9, similarly in Norcopensis (1679), 3; an almost identical expression is found in Possevino (1622), 71, but also in Erasmus' Institutio; Bushnell (1996), 99.

87 Norcopensis (1681), 4-7.

88 Medicalisation is often assumed to be a development of the modern (i.e. nineteenth century) world, but the term fits well in an early modern context as well. Compare, for example, Stephen Petrina, "The Medicalization of Education: A Historiographic Synthesis," History of Education Quarterly 46, no. 4 (2000), 504.

89 "effter hans wilckor, och det höga Embetetz Art och egenskap;" "den Leedsamheet och det mißhag till studia, som lättel: kunde insmyga sig utj hans Kongl: Högheetz sinne, om man wille beswära honom alt för myckit i förstonne med sådane obehagelige Grammaticaliska Underwijsningar i stället för angenähme, lustige, och nyttige historiske berättelser," Instruction, 17.

90 “hållas för een Leek och Lust," Instruction, 19. 
He was, in other words, already designated co-teacher at the trivial school in Uppsala, presumably already working as a teacher when he defended this dissertation. The subject matter has obvious bearing on his present and future profession. Most likely it is the words of Krutenius the practicing teacher we hear when we read that the work of a teacher is laborious: he must lecture, listen, repeat, admonish, punish, and so on, "as anyone who has taught in trivial schools can testify."

Professor Norcopensis was also-to use the terminology of the dissertation itself-both praeceptor publicus and praeceptor privatus. Furthermore, educational theory was a subject of the highest relevance to many of the students. A large part of them were at this time sons of clergymen who would in turn become ministers after their studies. For them, the teacher's profession was a potential career, even though it did not perhaps have the status of a parsonage.

Moreover, it is interesting to note how the dissertations seem to avoid rather than confront the issue of private versus public education. In fact, no distinction is made between them, although it is briefly mentioned that others discuss them separately. ${ }^{92}$ It is diplomatically stated that young boys should be given private instruction in parallel with their public schooling, as this prevents them from living in idleness, but also because they can thereby learn the ways of the region in which they will be serving the state. ${ }^{93}$

In De Praeceptore, the duties of the teacher are deduced from the etymology of the word praeceptor. They are divided in three: in essence, the teacher should prescribe, prevent and prohibit (although the actual etymology is not as straightforward as that). This means that he should both direct and order the studies and perform the duties of a parent in the parent's absence, shaping his pupil's character through example, encouragement, correction and discipline. ${ }^{94}$

Most importantly, and once more illustrative of the parallels between virtue ethics and formal schooling, the teacher must be such as he wishes the student to become. He must, first and foremost, teach by his own example. ${ }^{95}$ Young people more than others follow the examples of others, and they require a firm hand. Therefore, it is more important that the teacher is an honest, honourable man than that he is learned. Thus, virtue ethics is of central importance to the teacher just as it is for the student. The purpose of education appears to be equated with virtue: "For what is more sweet to a good nature, than following in the footsteps of his teacher and shaping his ways after his example?"96 This is dependent on the impressionability of youth: because they are so malleable it often happens that one can observe the vices of the teacher in the students, as in a mirror. ${ }^{97}$

\footnotetext{
91 Norcopensis (1681a), 8-9.

92 Norcopensis (1681a), 3-4.

93 Norcopensis (1685), 23-24.

94 Norcopensis (1681a), 3-4.

95 Norcopensis (1681a), 4-5.

96 "Nam quid dulcius bonae indoli, quam magistri sui vestigia insistere, atque ad ejus vivum exemplum mores suos formare." Norcopensis (1685), 23.

97 Norcopensis (1685), 5-6. Possevino (1622), 77, holds that it is more important that the teacher is "fide Catholicus" than that he is learned. The mirror metaphor is used by Pseudo-Plutarch (1927), $14 a$.
} 
The word education (educatio) comes from the Latin for "lead," which fits nicely with the idea of the teacher as an example. The teacher's act of leading is described as an Ariadne's thread leading through the labyrinth of vice to the road of virtue. ${ }^{98}$ The metaphor is perhaps most prominent in the Instruction, which describes itself as a "banister" (ledestång) and a "guideline" (ett Rättesnöre) for the preceptor, and it urges the prince to follow "every good path" (all good wäg) and avoid being wayled (wille stijgar).$^{99}$ It is stressed that the teacher must master the method of teaching, and that a good teacher is methodical. Unfortunately, the specifics of this method are not given in any detail. However the word "method" is used as a synonym for "road" "ratio," "methodus," "via"); a good teacher should be able to show the way to learning, and it is better to show the right way at once than to be able to return the students to it when already lost. Furthermore, it is important that the teacher excels in both the generals and the details. The impression is one of leading the students step by step. ${ }^{100}$ The method can therefore be understood as a form of guidance. Such a method would be closer to the practice of a private teacher than a lecturing professor.

The teacher should also be learned in those subjects he will be teaching, so that a "blind does not lead the blind." This is connected to the issue of individual talent, which is applicable to the teacher as well. For instance, one of the dissertations lauds the old Persian custom (as described by Plato) of having one teacher for each of the cardinal virtues. ${ }^{101}$ As the teacher must be attentive to students' individual gifts, one must also be very thorough in selecting teachers-everyone is not suited for this profession. ${ }^{102}$ But neither is everyone fit to teach everything. If one's knowledge is proper only for teaching younger children, one should not try and fail in working on higher levels. Such a teacher will often do a better job and enjoy it more than one who is more learned, the dissertation adds. ${ }^{103}$ In fact, this is a general problem: a teacher who possesses an all too "sharp ingenium" might react with anger at his students' sloth and ignorance, and this would be unjust. ${ }^{104}$ Interestingly, learning and good morals are not enough, although they are, as we have seen, very important. The teacher must also possess a certain "aptness for teaching" (aptitudo ad docendum). He should have a talent for the profession and a natural authority with children, so that they learn gladly and successfully. ${ }^{105}$ Here, perhaps more than anywhere else, the dissertations do come close to that slightly deterministic view of natural talent espoused by Vives and Huarte. ${ }^{106}$

98 Norcopensis (1685), 7-8. Ariadne's thread is also the metaphor used for the right teaching method in bishop Gezelius' preface to the Swedish edition of Comenius' Orbis (1682); Comenius (2006), 24; it is also found in Erasmus, De Ratione Studii, Erasmus (1971), 111. The road as metaphor for moral virtue has many older roots, in both Greek philosophy and the Bible.

99 Instruction, 2, 5.

100 Norcopensis (1679), 7-8.

101 Norcopensis (1681a), 9.

102 Norcopensis (1679), 4-5.

103 Norcopensis (1679), 7-8.

104 "acuto ingenio," Norcopensis (1679), 9.

105 Norcopensis (1679), 9.

106 It also contrasts with Quintilian who argued that the very best teacher will be an excellent teacher for young children as well as more advanced students; Quintilian (2001), 2:3:1-12. 


\section{Conclusion}

In conclusion, we can affirm that virtue ethics was central to the views on education presented in the dissertations from Uppsala university towards the end of the seventeenth century. The Aristotelian definition of virtue, which states that virtue is a good in itself, which simultaneously has good effects ${ }^{107}$ and that virtue is "nature perfected and brought to its height"108 is the philosophical basis for the weight put on moral philosophy in these pedagogical ideas. A good education does indeed bring knowledge, but, above all, it shapes good human beings through an activity, which disposes us towards virtue by habituating us in acting well. These ideas on the cultivation of one's individual ingenium are a moral philosophy turned into education. This is only natural, as Aristotelian virtue ethics was to a large degree always already an education turned into moral philosophy. This view also greatly influenced educational classics like Quintilian and Vives, who in turn influenced the authors of these dissertations.

The discussions of individual ingenia in pupils can also be seen as reflecting contemporary social developments. The educational system in seventeenth century Sweden was to a large part created to serve the requirements of a new form of state and a new society. The state administration had a great need of competent civil servants. In the era of Lutheran orthodoxy, higher levels of education among clergymen were required. In the bourgeois professions and the rapidly expanding armed forces, mathematics, science, and practical skills were in greater demand. As has been pointed out before, this led to a greater need for educational differentiation, and this differentiation was also reflected in great reforms of schools, gymnasia, and universities in the course of the century. As a result, it is clear that education could be a powerful vehicle of social mobility. The debate over delectus ingeniorum was a recurrent theme in Swedish educational history in the seventeenth century. ${ }^{109}$ The material dealt with here has shown very clearly that teachers on different levels in the system were intended to serve as a form of gatekeepers, selecting talents and directing them to such studies as they thought appropriate.

Just like literary historian Rebecca W. Bushnell, I would like to emphasise the double nature of early modern (humanist) education: it was full of paradoxes and balancing acts. It wished education to be both play and work, both free and regulated, both subjection and liberation. With Bushnell, I would also describe early modern humanist education as a tool, which could and was used for widely different purposes, and not a coherent ideology. ${ }^{110}$ The dissertations I have discussed seem to me to represent a socially progressive rather than conservative set of ideas in that they seem very useful for legitimating new relations of power and influence: They argue that, at least in theory, everyone can better themselves morally and intellectually through education. Few were selected for this education, but for those who were it could lead to the highest offices in church and government.

107 Norcopensis (1681a), 1-2.

108 "perfecta \& ad summum perducta natura," Norcopensis (1681a), 2.

109 Sjöstrand (1965), 204-5, 208, 232, 235-36, 257-58, 268-88.

110 Bushnell (1996), 17-20, 44, 73-76, 82-83, 114-27. In Bushnell's excellent work, the complex relationship between James VI (I) and his tutor, the celebrated poet and political writer Buchanan, serves to illustrate these contradictions in a striking way. 
The modern element in these texts is the medical model used to describe, analyse, and explain differences in talent, in both teachers and pupils. Bantock has argued that the seventeenth century was characterised by a general development towards greater differentiation in education, in tandem with increased differentiation in society at large. This was the reason behind the break with Renaissance humanism. It created "individual autonomy and personality differentiation" as a result of a differentiation of social roles, in his view. ${ }^{111}$ But, as we have seen, it also entailed a degree of medical determinism, which was a part of a general development towards determinism following the scientific revolution. And while this development could sometimes mean that the scope for social mobility was widened, the texts also bear witness to a wish to survey, judge, and control raw talents, as an important resource of the state.

$\overline{111 \text { Bantock (1980), 3 }}, 20,27,46,54-55,58,62,64,106-12,191-193,205-6$; quote on p. 3. 


\section{References}

\section{Archival sources}

Kungliga biblioteket, Stockholm

MS KB D 730: INSTRUCTION Huru then Kongl: Maij $\beta$ : Troo Man och Secreterare af Staten sampt hans Kongl: Högheetz, Printz CARLS Praeceptor, Edell och Wällbördig Andreas Nordenhielm uthj hans Kongl: Höghetz Uptuchtelse och Undervijsning sig hafwer ath rätta. Gifwen STOCKHOLM d 29 Martij Åhr 1690.

MS KB D761 (Notes of the crown prince Carl and his teacher Nordenhielm from the years 1688-1692).

\section{Printed sources and literature}

Annas, Julia. Intelligent Virtue. Oxford Scholarship Online, 2011.

Anton, Hans Hubert. Fürstenspiegel und Herrscherethos in der Karolingerzeit (diss.) Bonn, 1968.

Aristotle. Nicomachean Ethics. Cambridge, Mass.: Harvard University Press, 1934.

Bantock, Geoffrey Herman. Studies in the History of Educational Theory, vol 1. London: Allen \& Unwin, 1980.

Barclay, John. Icon Animorum or The Mirror of Minds, edited by Mark Riley. Leuven; Leuven University Press, 2013.

Biow, Douglas. On the Importance of Being an Individual in Renaissance Italy: Men, Their Professions, and Their Beards. Philadelphia: University of Pennsylvania Press, 2015.

Bureus, Johannes, ed. En nyttigh bok, om Konnunga styrilse och höfdinga [...]. Uppsala, 1634.

Bushnell, Rebecca W. A Culture of Teaching: Early Modern Humanism in Theory and Practice. Ithaca and London: Cornell University Press, 1996.

Carr, David and Jan Steutel. Virtue Ethics and Moral Education. London: Routledge, 1999.

Comenius, Johannes Amos. Didactica Opera Omnia. Amsterdam, 1657.

Comenius, Johannes Amos. Orbis Sensualium Pictus, edited by Lars Lindström. Stockholm: HLS Förlag, 2006.

Englund, Peter. "Böj ditt barns hals: Adlig barnuppfostran och skolning under stormaktstiden." In Barn i slott och koja, edited by Gösta Vogel-Rödin. Skövde: Västergötlands turistråd, 1986.

Englund, Peter. Det hotade huset: Adliga föreställningar om samhället under stormaktstiden. Stockholm: Atlantis, 1989.

Erasmus Roterodamus. Opera Omnia, vol I:2, edited by Jean-Claude Margolin. Amsterdam: North Holland, 1971.

Finnis, John. Aquinas: Moral, Political, and Legal Theory. Oxford: Oxford University Press, 1998.

Gambarota, Paula. Irresistible Signs: The Genius of Language and Italian National Identity. Toronto: University of Toronto Press, 2011.

Garin, Eugenio. Geschichte und Dokumente der abenländischer Pädagogik, I-III. Hamburg: Rowohlt, 1964-1967 [1957].

Grafton, Anthony and Lisa Jardine. From Humanism to the Humanities. London: Duckworth, 1986. 
Hellerstedt, Andreas. “The Absolute Hero - Heroic Greatness and Royal Absolutism in Sweden 1685-1715." In Shaping Heroic Virtue: Studies in the Art and Politics of Supereminence in Europe and Scandinavia, edited by Stefano Fogelberg Rota and Andreas Hellerstedt, 153-185. Leiden: Brill, 2015.

Hellerstedt, Andreas. "Introduction." In Virtue Ethics and Education from Late Antiquity to the Eighteenth Century, edited by Andreas Hellerstedt, 9-36. Amsterdam: Amsterdam University Press, 2018a.

Hellerstedt, Andreas. "Cracks in the Mirror: Changing Conceptions of Political Virtue in Mirrors for Princes in Scandinavia from the Middle Ages to c.1700." In Virtue Ethics and Education from Late Antiquity to the Eighteenth Century, edited by Andreas Hellerstedt, 281-328. Amsterdam: Amsterdam University Press, 2018b.

Hellerstedt, Andreas. "Praeses and Praeceptor: A Late $17^{\text {th }}$-Century University Dissertation as a 'Mirror för Princes.' In Early Modern Academic Culture, edited by Bo Lindberg, 161-176. KVHAA Konferenser, 97. Stockholm: Vitterhetsakademien, 2019.

Hidalgo Serna, Emilio. "The Philosophy of Ingenium: Concept and Ingenious Method in Baltasar Gracián.” Philosophy \& Rhetoric 13, no. 4 (1980), 245-263.

Hidalgo Serna, Emilio. "Ingenium' and Rhetoric in the Work of Vives." Philosophy \& Rhetoric 16, no. 4 (1983), 228-241.

Higgins, Chris. The Good Life of Teaching: An Ethics of Professional Practice. Malden: Wiley-Blackwell, 2011.

Huarte, Juan. Scrutinium Ingeniorum pro ijs, qui Excellere Cupiunt. Leipzig, 1622.

Jaeger, Werner. Paideia: The Ideals of Greek Culture, vol. 1-3, translated by Gilbert Highet. Oxford \& New York: Oxford University Press, 1965 [1939].

Koselleck, Reinhart. "Begriffsgeschichte und Sozialgeschichte." In Vergangene Zukunft: Zur Semantik geschichtliche Zeiten. Frankfurt a. M.: Suhrkamp, 2015 [1989].

Kristeller, Paul Oskar. Renaissance Thought and its Sources. New York: Columbia University Press, 1979.

Kristjànsson, Kristján. Aristotelian Character Education. London: Routledge, 2015.

Leinberg, Karl Gabriel. Om snillevalet (Selectus ingeniorum) i vår äldre skollagsstiftning. Helsingfors: Finska litteratursällskapet, 1884.

Lindberg, Bo. "Virtue and Duty: Academic Moral Discourse in Seventeenth Century Sweden." In Virtue Ethics and Education from Late Antiquity to the Eighteenth Century, edited by Andreas Hellerstedt, 179-206. Amsterdam: Amsterdam University Press, 2018.

Lindegren, Jan. "Den svenska militärstaten." In Magtstaten i Norden i 1600-tallet og de sociale konsekvenser, Rapporter til den XIX nordiske historikerkongress Odense 1984, bind 1, 99-143. Odense: Odense Universitetsforlag, 1986.

Lindmark, Daniel. Uppfostran, undervisning, upplysning: Linjer i svensk folkundervisning före folkskolan. Umeå: Umeå University, 1995.

Mehnert, Henning. "Der Begriff 'Ingenio' bei Huarte und Gracián.” Romanische Forschungen, 91, no. 3 (1979), 270-280.

Morgan, Teresa. Literate Education in the Hellenistic and Roman Worlds. Cambridge: Cambridge University Press, 1998.

Nilsson, Sven A. De stora krigens tid: Om Sverige som militärstat och bondesamhälle. Uppsala: Uppsala University, 1990. 
Norcopensis, Andreas/Jonas Bierchienius. De Modo Acquirendi Virtutes (pro gradu). Stockholm, 1679.

Norcopensis, Andreas/Johannes Krutenius. De Praeceptore et ejus Officio (pro gradu). Uppsala, 1681a.

Norcopensis, Andreas/Hemming Forelius. Gubernacula Imperii Togati. Ex Flor. lib. I. cap. 2. \$. 4. [...]. Stockholm, 1681 b.

Norcopensis, Andreas/Carolus Malmenius. De Educatione Liberorum per tres Priores Aetates (pro gradu). Stockholm, 1685.

Nordström, Kristina. Det sanna snillet: Genus och geni hos Thomas Thorild (PhD diss.). Stockholm University; Göteborg: Makadam, 2014.

Nussbaum, Martha. Cultivating Humanity: A Classical Defense of Reform in Liberal Education. Cambridge, Mass.: Harvard University Press, 1997.

Olden-Jørgensen, Sebastian. "Hvad er et fyrstespejl?" In Johann Damgaard, Alithia: Et dansk fyrstespejl til Christian IV, 9-42. Copenhagen: Museum Tusculanum Forlag, 2003.

Olden-Jørgensen, Sebastian. "Johann Damgaards Alithia (1597): Genrehistorie, teksthistorie og idehistorie: Omkring et dansk fyrstespejl til Christian 4." Fund og Forskning i Det Kongelige Biblioteks Samlinger 45 (2006), 35-55.

Persson, Mats. "Begreppshistoria och idéhistoria." in Trygghet och äventyr. Om begreppshistoria, edited by Bo Lindberg, 14-34. Stockholm: Kungl. Vitterhets Historie och Antikvitets Akademien, 2005.

Petrina, Stephen. "The Medicalization of Education: A Historiographic Synthesis." History of Education Quarterly, 46, no. 4 (2000), 503-531.

Plutarch. Moralia, vol 1. Cambridge: Harvard University Press, 1927.

Possevino, Antonio. Cultura Ingeniorum: Examen Ingeniorum Ioannis Huartis Expenditur. Cologne 1610.

Pufendorf, Samuel. De Jure Naturae et Gentium Libri Octo. Lund, 1672.

Quintilian. Institutio Oratoria, vol. 1. Cambridge, Mass.: Harvard University Press, 2001.

Scherp, Joachim. De ofrälse och makten: En institutionell studie av riksdagen och de ofrälse ståndens politik $i$ maktdelningsfrågor 1660-1682. Stockholm: Stockholm University, 2013.

Sellberg, Erland. "Berömmelse i döden: Om det rationella självmordet." In Utopin $i$ vardagen: Sinnen, kvinnor, idéer: En vänbok till Elisabeth Mansén, edited by Jenny Leontine Olsson, Anna Ohlsson, Ylva Söderfeldt and Jonas Ellerström, 235-260. Lund: Ellerströms, 2014.

Sjökvist, Peter. The Music Theory of Harald Vallerius: Three Dissertations from 17th Century Sweden. Uppsala: Uppsala University, 2012.

Sjöstrand, Wilhelm. Pedagogikens historia, vol. 2. Lund: Gleerups, 1965.

Skinner, Quentin. Reason and Rhetoric in the Philosophy of Hobbes. Cambridge: Cambridge University Press, 1996.

Slakey, Thomas J. “Aristotle on Sense Perception.” The Philosophical Review, 70, no. 4 (1961), 470-484.

Vives, Juan Luis. De Tradendis Disciplinis, in De Disciplinis Libri XII. Septem de Corruptibus Artibus; quinque de Tradendis Disciplinis. Leiden, 1636.

Ödman, Per-Johan. Kontrasternas spel: en svensk mentalitets- och pedagogikhistoria. Stockholm: Prisma, 1998. 